\title{
From responsible management to responsible organizations; the democratic principle for managing organizational ethics
}

\author{
Maarten J. Verkerk, Jan de Leede and André H.J. Nijhof
}

\begin{abstract}
An increasing number of organizations have adopted formal ethics programs. Almost all of these programs are institutionalized at a corporate level and based on communication with representatives and on hierarchical regulations. Sociotechnical theory suggests the use of a participative approach for managing ethics in an organization. In this approach, employees and other stakeholders are directly involved in setting the norms, or specifying the corporate norms in their own area of responsibility (the democratic principle). In this way, the internalization of organizational values is included in the process of organizing ethics.
\end{abstract}

\section{INTRODUCTION}

Nowadays the social responsibility of organizations is no longer disputed. Managers pay a lot of attention to codes of conducts and ethical programs. This development is gratifying, it shows that contemporary enterprises do recognize the interests of the various stakeholders. It also shows the willingness to address ethical issues while doing business. The thoughts given to social and ethical issues is related to the changing position of enterprises in today's society. It is no longer appropriate for companies to behave as if their owners, shareholders and bankers are the only important stakeholders. Within the company, there are various stakeholders with different interests, and also beyond the company.

In our opinion, the current reflections on ethical issues in today's universities and enterprises are one-sided. Firstly, much attention is given to big issues such as the Brent Spar affair concerning Shell, or the production capacity of Heineken and Carlsberg in Burma. An undesirable side effect of this attention is the suggestion that ethical behavior only concerns specific issues and not the daily activities of a company. Secondly, the focus of classical business ethics is on management. For example, the overview by Collins ${ }^{1}$ of the first 1500 articles in the Journal of Business Ethics, showed that the most researched topic was ethical sensitivity in the decision-making process. This focuses attention on the decision-makers, e.g. line managers or heads of staff departments. This attention is reflected in the codes of conduct. Generally, the code of conduct of a company reflects the ethical values that the company considers important within the decision-making process. An undesirable side effect of this focus is the suggestion that ethical behavior concerns first and foremost the activities of managers, and not the activities of all employees in an organization.

This article, however, has a different topic. Here, attention will be focused on 'small' ethical issues that arise every day on the shop floor of an industrial organization. In particular, attention is paid to the ethical aspects of the daily activities of individual employees or groups of employees. The conditions that will stimulate responsible actions on the shop floor will be investigated. In our experience, 'small' ethical issues arise every day on the shop floor. These 
issues often have a limited impact, the effects of violating the ethical norms are bounded. However, 'small' issues can also have a large impact. For instance, small infringements of the environmental norms can be the prelude to an environmental disaster. The same applies to safety and health instructions. On the production floor, the combination of a few minor infringements can easily result in a serious pollution of the environment, severe injuries to colleagues, or even fatal accidents.

Our focus on small ethical issues on the shop floor emphasizes the responsibility of all employees of a company: that is both operators and management. It is the individual employee, or the group of employees, that has the responsibility to behave according to the norms and values of the organization. They have to make ethical decisions on a day-to-day basis. From the point of view of the shop floor, the key question is not whether managers behave responsibly in their decision-making process or how organizations behave responsibly by the development of a code of conduct or an ethics program. Rather, the key question is what structural and cultural conditions have to be fulfilled so that the employees on the shop floor of an organization can behave and will behave in an ethically responsible way. Naturally, these structural and cultural conditions have to be created for a large part by the management ${ }^{2}$.

In this article, we adopt the sociotechnical systems view ${ }^{3}$, in which the role of the responsibility and authority of (groups of) employees to control their own workplace is emphasized. Furthermore, the participative process for deciding about issues that are directly related to the shop floor is stressed. This seems to be a fruitful starting point in addressing ethical responsibilities on the shop floor.

Our approach is summarized in a double reading of the title of this paper. First, the title reflects the change of the focus of ethical reflections from the 'classical' center on responsible managers towards the responsible organization as a whole. Second, it also draws the attention to the process of organizing responsibilities. In developing sound ethical behavior throughout a company the managers still have to take the lead. They have to develop the conditions in which the employees on the shop floor can and will behave responsibly.

The outline of the paper is as follows. In section 2 , the frequently used corporate approach to ethics programs in organizations is analyzed, showing the strengths and limitations of this approach. Then we describe, in section 3, a case study at a Philips' plant. Here, we show how the mini-company concept - as an extension of the sociotechnical concept of the semi-autonomous work group - acts as a mechanism in which structural and cultural conditions are created for employees to behave in a responsible way. This case study also shows that a responsible organization requires a participative democracy: top-down and bottom-up processes have to be balanced. The implications for managers are manifold. In section 4, the theoretical background to the mini-company concept, and sociotechnical systems theory, are presented. In section 5, we discuss the implications of this approach. In our view, this is a step beyond the corporate approach to ethics programs. Participative democracy is oriented towards developing a responsible organization.

\section{CORPORATE APPROACH TO ETHICS PROGRAMS}

Since the research on ethics in a business environment has developed a more institutionalized character, there is increasing attention on organizing ethical behavior. Initially, this attention focused on determining factors that stimulated or blocked ethical behavior. Bartels ${ }^{4}$ proposed one 
of the first models in this area which highlighted causality in ethical decision-making processes. Later, interactionist models and issue-related models were developed ${ }^{5}$.

In the late 1990s, the focus shifted from ethical decision-making models towards ethics programs for corporate social responsibility. This shift can partly be explained as a logical sequence in the development of theory. The research on ethical decision-making shows a strong influence by organizational factors on ethical behavior. These organizational factors are the core of ethics programs. Another explanation can be found in the external pressures on organizations such as the revised provisions in the Sentencing Guidelines in the USA, and the Cadbury Report and its recommendations in Europe. In literature, there is no widely accepted definition of ethics programs. Ferrell et al. ${ }^{6}$ state that an effective ethics program is a process of continuous activities that are designed, implemented and enforced to prevent and detect misconduct. Weaver, Trevino and Cochran ${ }^{7}$ mention common elements of formal corporate ethics programs including:

- Formal ethics codes, which articulate a firm's expectation regarding ethics;

- Ethics committees charged with developing ethical policies, evaluating company or employee actions, and/or investigating and adjudicating policy violations;

- Ethics communication systems, providing a means for employees to report abuses or obtain guidance;

- Ethics officers or ombudspersons, charged with coordinating policies, providing ethics education, or investigating allegations;

- Ethics training programs, aimed at helping employees to recognize and respond to ethical issues; and

- Disciplinary processes to address unethical behavior.

The above-mentioned definition of ethics programs, and the common elements, clearly stem from a hierarchical viewpoint on the functioning of organizations. The ethics programs aim at standardizing the behavior within an organization by articulation, evaluation and regulation of the expected behavior. Paine ${ }^{8}$ indicates that this standardization is achieved by a combination of two different control orientations. Compliance-orientation embodies a coercive element towards control, emphasizing adherence to rules and disciplining misconduct. Values-orientation aims at standardizing behavior by developing shared values and encouraging ethical aspirations. Despite their differences, both approached have in common the desire to standardize corporate behavior. The underlying assumptions are that attention should be focused on the role of the manager and that ethical behavior should be standardized on a corporate level. In this article, we question these assumptions.

The corporate approach towards ethics programs has certain serious limitations.

1. The problem of internalization. Ethics programs prove to be more effective when employees have internalized the ethical values ${ }^{9}$. However, corporate ethics programs are based on developing ethical policies by communication with representatives in combination with hierarchical enforcement of compliance. Such an approach does not inherently lead to the internalization of ethical values. On the contrary, since these policies stem from the 'other side'. 2. The problem of a legalistic attitude. A program aiming at compliance to standardized behavior tends towards a legalistic point of view ${ }^{10}$. Although legal compliance is in itself an important aspiration, it covers only one part of the whole range of ethical behaviors. For example, within the process industry an important ethical value is not to leave a mess in the production area for the next shift, although this topic is untouched by law. 
3. The problem of contextualization. Compliance with corporate ethical standards presupposes that such rules can be applied unambiguously in practice. The literature on ethics of care emphasizes that every situation is different because of the history leading to that situation and the unique interests and values of the people involved ${ }^{11}$. With this view, the moral responsibility of employees can only be understood in a concrete situation. This view is supported by everyday practice on the shop floor. This implies that the general statements contained in codes of conduct must be contextualized in order to be effective on the shop floor.

4. The problem of effectiveness. These limitations must lead to a weakening of the effectiveness of an ethics program at all levels of the organization. Due to cumulative effects, the effectiveness of such a program will decrease with an increasing distance from the top level.

These problems need a different approach in which ethical behavior is internalized, is contextualized, and encompasses a broader perspective than only a legalistic view. We believe that an interesting opportunity is provided by the development of participative democracy in organizations. 'Participative democracy' is used here in the sense of having the authority to control and make decisions about ones own workplace ${ }^{12}$. This article explores the characteristics of an organization where ethical values are organized using a participative democracy. An important consequence of this approach is that corporate ethical standards are not implemented in a one-way top-down process. In a participative democracy, ethical standards are developed in a two-way process involving both internal and external relationships. In this process, corporate standards will function as a framework that has to be elaborated upon and specified for the group or department and its relationships. Furthermore, this dialogical process will lead to the development of context specific standards that cover issues beyond the general corporate standards. Hence, in a participative democracy, the standardization of ethical policies will be focussed on the level where the people concerned are directly involved in elaboration, specification, development, and controlling ethical policies. Such a bottom-up process stems from the sociotechnical literature and this is why we call this principle the democratic principle for organizing ethical behavior.

Before exploring the theoretical implications of the democratic principle for managing ethical behavior, the next section presents a practical illustration of this approach.

\section{CASE STUDY AT PHILIPS ROERMOND}

The case study is of a business unit at the Philips plant in Roermond. Data on this plant were collected between 1994 and1996 ${ }^{13}$.

\section{Market and product}

In 1992, Philips Components decided to start a new business unit at Roermond. The new business unit was responsible for the development, production and marketing of Ceramic Multilayer Actuators (CMAs). The market prospects were promising from the start, especially since the demand for actuators for ink-jet printers was rapidly increasing. In this application, the CMA induces a pressure wave in the head of the printer, which causes the ejection of a small droplet of ink. At the time, the market for ceramic multilayer actuators was very dynamic. The main characteristics were short time-to-market, high volume flexibility, high mix flexibility, and very tough competition. These characteristics determined the market position of the CMA business unit: a sub-contractor for a company operating in the turbulent ink-jet printer market. The 
dynamic situation caused by the market was further increased by the complexity of the product: an actuator is a new high-tech product manufactured using a new technology. The product itself was not yet ready for production. Further development was needed in co-operation with the Japanese customer. Co-development - in co-operation with both the customer and certain suppliers - was needed. Only then, could the technological problems be solved.

These characteristics of the product and the market imply high demands on the organization. The solution was sought in concurrent engineering - that is, overlapping the development and production stages. The product went into production, although it was not fully developed. Test series were made in the factory, not in the laboratory. This required very intensive co-operation between production and development. In addition to using the concept of concurrent engineering, continuous improvement was also needed to ensure higher yields, better quality and timely delivery.

The production process included the processing of materials containing lead. Environmental considerations encouraged the management to control the production process, the exhaust of gases, the disposal of waste water, and the handling of other waste materials with care.

\section{Design and implementation of mini-companies}

The mini-company concept was introduced in 1994, after two years of factory operation. In fact, it was no more than an intensive continuation and formalization of former management policies. Between 1992 and 1994, the business unit grew from 25 to 125 people. The production quality and yield had to be enhanced dramatically. The general approach was characterized by a focus on process control and step-by-step improvements. Instead of aiming for breakthroughs through major innovations, the organization focused on many small improvements which were achieved by an interdisciplinary approach: the joint efforts of operators, factory engineers, development engineers, repair and maintenance technicians, quality engineers, and purchasing agents. This interdisciplinary approach was realized in practice by means of improvement teams. For example, in the start-up phase of the manufacturing operation, many so-called Process Inventory Teams were initiated to deal with problems in one specific part of the process. Generally, these teams consisted of one or two operators, one factory engineer, one developer, one line manager, and, depending of the problem, other indirectly involved employees. The results of these improvement teams were very promising. The control of the process, the yield at every stage, the quality of the products, and the efficiency of manufacturing improved. At the same time, many small improvements that supported the employees in their daily operations were implemented. In 1994, the specifications set by the customers were tightened. Again, the organization faced a challenge. In response, the factory management introduced the mini-company concept as proposed by Kiyoshi Suzaki. This concept served as a metaphor: every unit should be viewed as one little company within the larger company. Every unit should act as a small company with customers, suppliers, bankers, employees, equipment etc..

The structural basis of the mini-company is the unit structure, designed on sociotechnical principles. In particular, the Dutch design approach was used, based on the work of Ulbo de Sitter. The units are responsible for a distinct phase or complete part of the process. The boundaries of each phase or part are well defined and carefully chosen. The basic principle is that within a unit the number of internal relationships should exceed the number of external relationships. Such a unit is designed to be a mini-company. In other words, a mini-company does not cover all the operators from one shift of the whole manufacturing process, but rather it includes all the operators from all five shifts of a distinct phase or complete part of the 
manufacturing process. Consequently, it is intended that the operators should identify themselves with their unit covering all five shifts. The process for the manufacturing of the actuators was split into six distinct units: 'foil casting', 'screen printing', 'sintering', 'dicing', 'application of terminals', and 'packing'.

The hierarchy within Philips CMA consisted of four layers: general manager, factory manager, unit-leader and operator. Every shift had one senior operator and several other operators. Operators worked on a five-shift schedule. There were three unit-leaders, who controlled between 16 and 55 employees. All the employees of a unit, including the unit leader formed a mini-company. All members of the mini-companies had to follow a training program. In this program, the mini-company philosophy and the mini-company process was explained. In addition, improvement techniques were taught.

\section{The mini-company process}

The mini-company process incorporates two separate cycles, a nine-step cycle and a seven-step cycle. These cycles are indicated in Figure 1.

\begin{tabular}{|c|c|}
\hline 9-step cycle & 7-step cycle \\
\hline 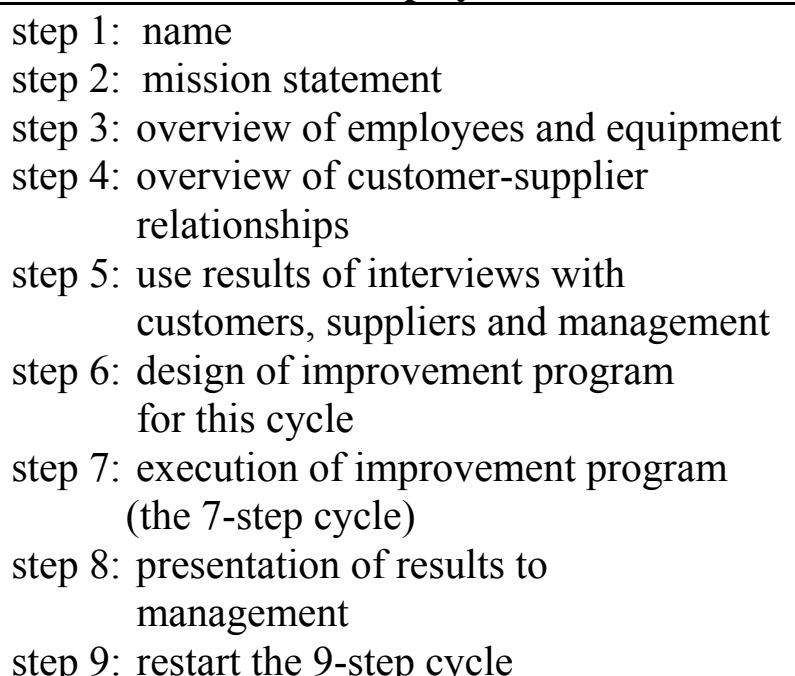 & $\begin{array}{l}\text { step 1: describe the problem } \\
\text { step 2: collect data } \\
\text { step 3: find the causes } \\
\text { step 4: develop a plan } \\
\text { step 5: execute the plan } \\
\text { step 6: check on desired results } \\
\text { step 7: standardize the } \\
\text { improvement }\end{array}$ \\
\hline
\end{tabular}

\section{Figure 1. The 9-step cycle and the 7-step cycle}

The nine-step cycle is a long-term process and takes about one year to complete. This cycle is a modification of the one described by Suzaki. The most important activities of each nine-step cycle are the formulation of the mission statement, the identification and interviewing of suppliers and customers, and the design and implementation of an improvement program. Small groups of operators interview their suppliers, customers and management. Based on these interviews the mini-company itself defines its mission statement and sets the priorities for the needed improvement activities. Management indicate several areas in which improvements could be realized: quality of the processes or the products, the costs of the production process, the delivery performance to the (internal or external) customer, safety and environment, motivation (morale) of the group, and housekeeping. During the nine-step cycle a special meeting was organized in which the mission and improvement program were presented to the management. In general, the mission and improvement programs of the mini-companies were approved by the 
management without any changes. In some cases, the management convinced the members of the mini-companies that their mission was not complete or that the priorities of the improvement program should be changed. The management never imposed a change to the mission or the program on a mini-company. In this way, management showed that it valued the contribution of the mini-companies based on solid arguments. Figure 2 gives, as an example, the mission and improvement program of the 'foil casting' mini-company for 1996.

\section{Mission of 'Foil casting' mini-company}

To achieve a satisfied (internal and external) customer in an efficient way by:

- working according to the process instructions;

- working as a team to realize improvements both within the unit and for the customers and suppliers;

- communicating well between the different shifts by means of a systematic shiftchangeover method and unit meetings;

- communicating informally with customers and suppliers about the quality of the deliveries;

- taking responsibility both individually and as a team for the housekeeping in the unit.

Roermond, February 1996

Note:

The unit defined the suppliers of ceramic powder and organic binders as their main (external) suppliers.

The unit defined the 'screen printing', 'sintering', 'packing' production units, and the development group (for trials) as their main (internal) customers.

\section{Improvement program of the 'Foil casting' mini-company}

The following improvements have to be realized:

- up-dated process instructions;

- development of a complaints procedure (complaints from customers);

- reduction in the number of complaints;

- improved agenda for the monthly unit meetings, i.e. add topics covering delivery performance, complaints, information of factory engineering and development, and customer comments;

- reduced powder and foil waste;

- improved ergonomics in the wet room.

Roermond, February 1996

\section{Figure 2. The mission and improvement program of the 'Foil casting mini-company in 1996.}

The improvement program of the mini-company is executed using improvement teams. A team works on one of the issues from the improvement program. Using the seven-step cycle the issue is tackled systematically. The seven-step cycle is a short-term cycle, lasting about two to three months, and is, in fact, an extended version of the Plan-Do-Check-Action circle. The only difference is that the planning stage is broken down into four phases. Generally, an improvement 
teams consists of one operator from each shift, one line manager, and, depending on the problem, technicians from Repair \& Maintenance, and/or engineers from factory engineering, quality engineering or development. The chair of the improvement team is in most cases the unit-leader.

To illustrate the achievements by the mini-companies, some examples of improvements realized are provided. Several mini-companies improved their shift changeover procedures. One mini-company changed the layout of their unit. Another mini-company reduced the frequency of maintenance activities and also the number of registrations in the Computer-AidedManufacturing system was significantly reduced. Another improvement team focused on a specific quality problem and identified the hidden process parameter causing the problem. One team reduced the waste of materials and exhausts to the environment.

\section{Effects}

The benefits from the development of mini-companies in this plant were manifold. Many operators obtained more knowledge on their own process, because they were better able to see the bigger picture. The number of systematic contacts with internal and external customers, and with internal and external suppliers is high, indicating the existence of intensive information exchange relationships. Another important effect is the significant contributions of the minicompanies to the improvement and innovation programs.

Turning to our topic of ethical responsibility on the shop floor, we present here some data on the issue of power and trust. The authority to control and to decide about ones own workplace is an organizational condition for stimulating ethical working methods on the shop floor; and a high level of trust between employees, and between employees and management, is a cultural condition that encourages responsible behavior.

We have measured the power relationships using the control graph (see figure 3), an instrument developed by Arnold Tannenbaum ${ }^{14}$. These data are based on a survey that took place in mid-1995 among the first group of 102 operators to become involved with the mini-company concept.
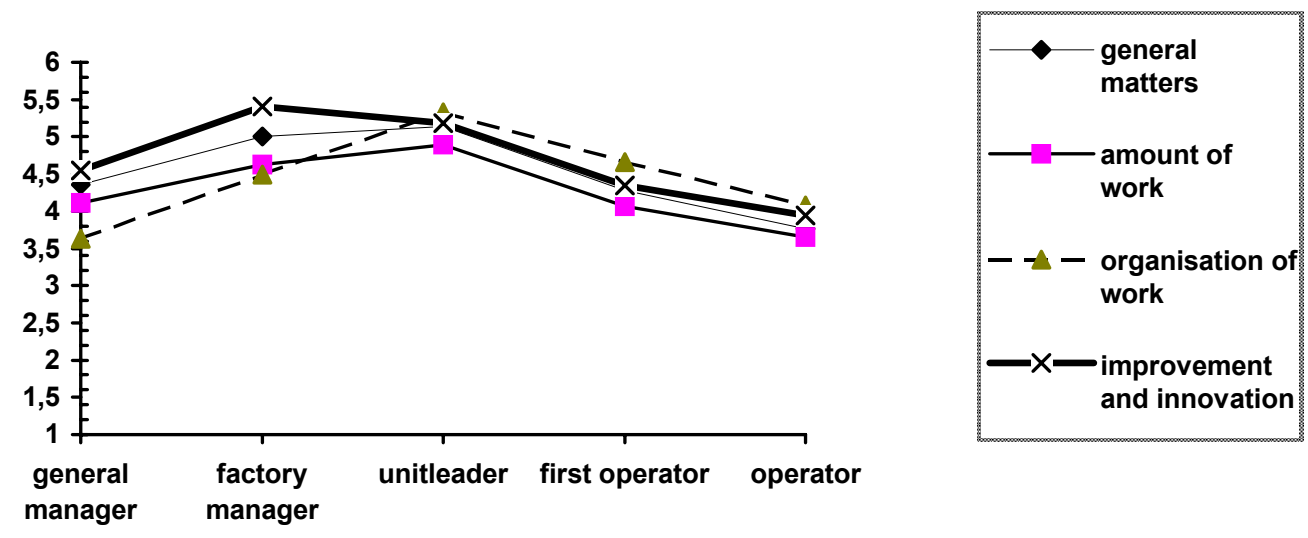

Figure 3. Control graph $(N=102 ; 1=$ very little influence, $6=$ great influence $)$

This control graph shows the level of influence of all the hierarchical levels as perceived by the operators. Four areas of influence were measured: general matters, amount of work, organization of work, and improvement and innovation. It is worth remarking that these four items cover the agenda of the monthly unit meeting (produced numbers, quality, deliveries, customers, safety and 
environment, state of the art of the improvement teams); as well as the subjects indicated by the management in the nine-step cycle with which improvements have to be realized (quality of processes and products, costs of the production process, delivery performance to the internal or external customer, safety and environment, motivation or morale of the group, and housekeeping).

This control graph shows a high level of influence in all areas. Two characteristics should be highlighted. Firstly, the perceived influence is rather high for all hierarchical levels. This indicates, in the words of Tannenbaum, a large total amount of control, which is an indicator of the effectiveness of the organization. Secondly, the differences in influence of the various hierarchical levels are rather small. In other words, the operators perceive their own amount of control to be almost on a par with that of the management. This finding was confirmed by many interviews with operators. They all indicated that 'nowadays' the management listened to their arguments and that they were allowed to improve their own work situation. They also acknowledged that this implied more responsibility and pressure on themselves. These findings might have important implications. The first characteristic suggests that the organization will be effective in implementing responsible behavior; the second characteristic suggests that employees indeed have the power to work in a responsible way.

The findings on power are reflected in the level of trust between all the hierarchical levels. In this example, $85 \%$ of the operators stated that they had trust in the management, which is quite high by normal industrial standards. Observations and interviews supported this finding. Many operators, who had worked in other Philips plants, expressed their greater trust in the management of this factory. They were certainly aware of the changes in responsibilities and powers, but had a simple trust in their managers who were very open over market and strategic issues. These strong trust relationships are in line with the successful implementation of the minicompany concept, and with the real changes in management style reported by the operators. The trusting relationships suggest that the cultural conditions needed to stimulate ethical behavior were present. 


\section{SOCIOTECHNICAL SYSTEMS: THEORY AND RESPONSIBILITY}

The Roermond example shows a Dutch variant of Sociotechnical Systems combined with the mini-company idea conceived by the Japanese consultant Kiyoshi Suzaki ${ }^{15}$. We can identify four geographically distinct variants of contemporary Sociotechnical Systems (STS): the Australian, the Scandinavian, the North American and the Dutch ${ }^{16}$. The Dutch variant is primarily oriented at developing a design theory and a design methodology for a democratic organization. In a recent article, Frans van Eijnatten and Ad van der Zwaan concluded that an ideal shared by all STS approaches is 'participative democracy in the workplace'. Furthermore, they note that the different approaches are merging ${ }^{17}$.

In this section, we describe briefly some relevant conceptual developments in the Dutch variant, and the theory underpinning the mini-company concept.

\section{Dutch STS}

The Dutch variant - Integral Organization Renewal - offers a detailed design theory and design methodology. This variant claims to have an integrated approach to such diverse phenomena as quality of the organization, quality of work life, and quality of labor relations through the design of the architecture of the systems structure. Ulbo de Sitter et al. recognize that the open systems approach is much more than simply a Quality of Working Life (QWL) approach and that, therefore, 'functional requirements with respect to customers, the physical environment, the labor market, suppliers of capital, workers, etc., should be regarded as equivalent ${ }^{18}$. The concepts as developed and used within the Dutch variant include a distinction between the production structure, the control structure and the information structure, as well as the logic of designing them in this sequence. Detailed design principles regarding paralleling and segmenting product flows are given. Additionally, the concept of the complete task is central to the Dutch STS. The aim is to reduce the complexity of an organization and to create primary work groups that are responsible for a complete product flow, from beginning to end. The primary work groups have control over purpose, context and system dynamics.

On a conceptual level, the work of De Sitter on control capacity of primary work groups is of importance. His specification of the control capacity in the decision table is comprehensive, including internal/external decisions and routine/non-routine decisions. This implies that employees have the authority to control and make decisions about their own workplace. Therefore, one can conclude that the result of the Dutch design approach is a democratic workplace.

However, we have three comments on this design approach. Firstly, a close examination of the detailed design principles at the work group level reveals that the words customer and market are not mentioned at all. The market and the customer are present in the design of the production structure at the macro level, but not in the micro-level design of the primary work group. In addition, the industrial applications in Dutch companies do not illustrate the farreaching possibilities of the theory. Secondly, the Dutch variant is a typical design approach. Although the result is the desired democratic workplace, the path towards this goal is not necessarily democratic. Rather, the Dutch approach depends to a large extent on expert knowledge defining the new structure for the employees. In terms of a participative process towards a new design, much can be learned from other traditions within STS, such as the Australian and Scandinavian variants. Thirdly, the Dutch variant has not developed tools and 
methods for continuous improvement in a participative process. In this area, much can be learned from the mini-company concept as developed by Kiyoshi Suzaki.

\section{The mini-company concept}

With respect to the external orientation of STS, our earlier contributions (see note 13) take the Dutch STS variant one step further. We have developed the mini-company concept of Suzaki both conceptually and in practice within an STS context. Within the mini-company concept, the primary work groups do have interactions with customers and suppliers. The primary work groups manage their business relationships, both internally and to an extent externally of the company.

Suzaki coined the term 'mini-company' for primary work groups that are responsible for their customer and supplier relationships. An organization is viewed as a collection of minicompanies. Each work group within the organization has its own process (or group of processes). For every unit, the subsequent process is viewed as the customer and the previous process is viewed as the supplier. In our way of thinking, it is possible and useful to use the term 'minicompany' as a metaphor when thinking about the organization of a factory. The word 'minicompany' suggests ideas, such as mission (strategy), entrepreneurship, and customer-supplier relationships.

The structural basis of the mini-company is comparable to the STS view of primary work groups ${ }^{19}$. The mini-company is responsible for a complete task, has the authority to make decisions about its own workplace, and has a high level of group autonomy. The amount of control capacity is similar to that of normal STS primary work groups. The mini-company however is much more oriented towards the customer and the market. This has implications for the design and management of such primary work groups. The mini-company has four characteristics that are distinct from sociotechnical primary work groups:

1. The mini-company has a name and a mission statement. The mini-company itself formulates both of them. This relates to control over purpose.

2. The mini-company identifies its customers and suppliers, and is responsible for managing its relationships. While it may not always be appropriate for external customers and suppliers to have direct contacts with the mini-company, there are always internal customer-supplier relationships. This amounts to control over context.

3. The mini-company is responsible for its own improvement programs. Based on its contacts with customers, suppliers and management, the mini-company is able to identify its weak points and plan improvements. This characteristic entails control over system dynamics.

4. The mini-company presents its name, mission, members, customers, suppliers, improvement programs, and results, on display walls. This was labeled 'glass wall management' by Suzaki. Everyone, including strangers, must be able to see and understand the process and the actual situation.

One characteristic of the mini-company - as the Roermond case study highlighted - is the minicompany process. This is the dynamic side of the mini-company concept and is largely standardized and structured. It can be represented as a nine-step cycle (see Figure 1) in which, in every period, the name and mission are under review, and the relevant customers and suppliers are identified and visited. These visits are intended to be overall assessments of the minicompany. In completing the cycle of the mini-company process, the requirements of the internal or external customers and suppliers are made visible to the mini-company by itself. These requirements become the inputs for the improvement program. Every selected improvement 
action is carried out by an improvement team, consisting of members of the mini-company and other relevant people from support functions. Again this implies a structured approach (the seven-step cycle shown in Figure 1). At the end of each cycle, the results are reported to management. Since the nine-step cycle is a continuous process (step 9 restarts the nine-step cycle), the functioning of the mini-company is evaluated regularly against market requirements. Central to both the nine-step and the seven-step cycle is the involvement of the members of the mini-company: they own the program and they execute all the steps.

The Roermond case showed the comprehensiveness of the standards and performance indicators of the mini-company. If it is truly to be a mini-company, the performance indicators must encompass not only the efficiency of the factory but also the quality, the health, the safety, the environment and the morale of the employees.

The mini-company is well equipped to establish the structural aspects of the primary work group. However, the case outlined above showed that it is not only a matter of proper structural design, it also concerns the social-dynamic aspects of managing these primary work groups. Here, the style of management has repercussions for the power and trust relationships within the organization. The members of the mini-companies need to be convinced that the management really wants to share power. This creates the necessary trust between the hierarchical levels. In the next section the implications of this organizational concept for our topic, responsibility and ethics on the shop floor, are discussed.

\section{EVALUATION}

In the introduction, we summarized our approach through a double reading of the title. This double interpretation will also be used as a guide in the evaluation of the findings.

\section{Responsible organization}

The first reading of the title reflects the change in the focus of ethical considerations from the 'classical' center on managers towards the responsible organization as a whole. We have shown that, in the mini-company process, structural conditions have been created to enable the change of focus by the development of a participative process for norm setting and improvement. The most important structural conditions are the design of the primary working group, the minicompany process, and the style of management.

In the first structural condition, the design of the primary working group, the main elements are the production structure, the control structure, and the information structure. These structures have to be designed in conformity with the concept of the 'whole task'. This is in line with STS literature, see notes 17 and 18.

The second structural condition, the mini-company process (nine- and seven-step cycles), includes the identification of important areas for improvement (quality, costs, delivery, safety and environment, morale, and housekeeping). In particular, the mini-company process is a powerful tool in the participative process of norm setting and improvement. Management can input their views on responsible behavior during the interview stage (step 5 of the nine-step cycle), in affirming the improvement program (step 6 of the nine-step cycle), and in the evaluation of the performance of the mini-factory (step 8 of the nine-step cycle). Employees themselves formulate the mission (step 2 of the nine-step cycle), design the improvement program (step 6 of the ninestep cycle), and execute the improvement program (step 7 of the nine-step cycle). Furthermore, in 
the monthly unit meetings, minor improvements can be discussed and executed. Participative processes lead to the development of feelings of ownership and commitment ${ }^{20}$. These feelings are an important condition for responsible behavior ${ }^{21}$.

The third condition is the appropriate style of management (open, visible, and participative). This condition reflects the personal attitudes and basic beliefs of a manager and has both structural and cultural sides to it. In the framework of the topic of this paper, it refers to the willingness and capability of a manager to develop a participative organization. The development of such an organization implies changes in the patterns of power. In a participative organization, employees have the authority to decide about their own workplace. This authority is an essential condition for responsible behavior. In the final analysis, the shop floor is the heart of the company: there, and only there, can transformation processes take place. Particularly in the sociotechnical tradition, it has been emphasized that one of most important objectives of the hierarchical line, the technical departments, and the staff departments, is to support the primary production process. In other words, the hierarchical line, the technical departments, and the staff departments, all have to create the conditions for responsible behaviour on the shop floor.

Evidence supporting an open, visible and participative style of management is provided by the control graphs (Figure 3). They show the major influence of all hierarchical levels in the organization. From these graphs two conclusions can be drawn. Firstly, a significant amount of power is present throughout the whole organization. According to Tannenbaum, this means that the organization will be effective in realizing its objectives. In the mini-company process the following objectives (areas of responsible behavior) have been identified: quality of the products, costs of production, delivery performance, safety and environment, motivation (morale) of the group, and housekeeping. The reason behind the relationship between large amounts of power and effectiveness is that the total amount of power is an indication of the intensity of the exchange relationships between hierarchical levels. The intensity increases when employees from different levels meet each other, exchange information, make joint decisions, and implement these decisions together. These intense exchange relationships are positive for both the quality of the decision-making process and the speed of implementation within the company. Secondly, the operators perceive themselves to have a large amount of power (only slightly lower than management). In other words the shop-floor employees experience that they have the authority and the power to make decisions about their own workplace. The same holds true for the unit or mini-company: it has the authority and power to realize its objectives as defined in the nine-step process. In view of these conclusions, it is tempting to interpret the measurement of power as a tool for measuring responsibility, and to read the control graph as a responsibility graph.

The Roermond case shows that when an organization applies democratic principles it is possible to organize effectively the day-do-day ethical issues. The mini-company process gives an employee the authority to decide about his or her own workplace. At the same time, the ethical standards are specified and contextualized by the employees themselves. However, these characteristics do lead to important questions. Does authority on the shop floor not lead to misuse or chaos? Does contextualization of norms not lead to unethical behavior or losing sight of the objectives of the company? These questions arise because managers cannot control the minicompany process directly because they are not present during all steps of the nine-step cycle. In addition it should be noted that in the Roermond case no formal ethics program was present although this issue was discussed intensively before the mini-company process was started. Both the responsible manager $(\mathrm{MJV})$ and the researcher $(\mathrm{JdL})$ were quite curious about the course the process would take. To their surprise, the participative process 'effortlessly' resulted in the 
internalization and contextualization of responsible behavior. Seldom did management need to intervene. In our view, this result was obtained because the management, despite the absence of a formal ethical code, had informally transferred successfully ethical norms.

\section{Lead of management}

The second interpretation of the title draws attention to the process of organizing responsibilities. In our opinion, managers still have to take the lead in developing sound ethical behavior. They have to take the initiative to start an ethics program. They have the power to fulfil the organizational conditions and last, but not least, they have to set an example.

In our view, the lead by management cannot be overestimated. The asymmetry in the employer-employee relationship, and the actual functioning of power, in an organization implies that an employee or group of employees can never develop responsible behavior without the support of management. In the corporate approach to ethics programs, this responsibility of a manager is well recognized. In addition, we would like to emphasize the responsibility of the manager in developing his or her organization into a participative democracy. De Sitter $^{22}$ remarks that it is impossible to transform an undemocratic structure in a democratic manner. Indeed, the development of a participative organization requires strong management to overcome resistance and to fulfil structural conditions. Nevertheless, in management-guided change processes many democratic steps can be incorporated.

The development of a participative democracy is much more than the design of primary working groups and the start of the mini-company process. The proof of the pudding is the eating, the proof of a responsible organization is the behavior and the example of management. In management circles, an open and participative style of management to empower employees is frequently recommended. However, despite all the talk and the change programs, most managers prefer a command-and-control model ${ }^{23}$. Increasingly, management appears to be the largest obstacle in the development of a participative organization. However, they have to take the lead, the development of a responsible organization requires a style of management that is in agreement with participation and empowerment. Only a participative democratic process can bring with it the internalization and contextualization of ethical behavior.

\section{Trust and effectiveness of ethical programs}

The case study also demonstrated the link between trust, power, responsibility and the effectiveness of ethical programs. Hosmer, has completed an extensive literature study on trust. In his view, trust is the connecting link between organizational theory and philosophical ethics. He summarizes the findings from organizational studies about trust in the following definition: "Trust is the reliance by one person, group, or firm upon a voluntary accepted duty on the part of another person, group or firm to recognise and protect the rights and interests of all others engaged in a joint endeavour or economic exchange" 24 . This definition it is all about the rights and interests of others. What does it mean to recognize and protect the rights and interests of others? This question belongs to the field of moral philosophy. From the perspective of business ethics, a practical answer to this question is given by the ethics program of a company. Generally, an ethics program identifies the 'others' (the stakeholders involved), and describes their rights and interests (the do's and don'ts). Here, the connection between organizational theory and philosophical ethics comes to the fore. In organizational theory it is stressed that trust is essential 
to understand the behavior of individuals, the behavior of groups, and the effectiveness of management ${ }^{25}$. A high level of trust in an organization reflects that all the parties involved are convinced that successful cooperation to realize the joint endeavor and economic exchange will serve their rights and interests. Specifically, a high level of trust in an organization indicates that all the parties involved believe that respecting the ethics program during day-to-day activities will serve their rights and interests. In other words, trust stimulates ethical behavior.

What can managers do to initiate and build trust? Whitener et al. ${ }^{26}$ have identified five categories of behavior that influence the employee's perception of a manager's trustworthiness: behavioral consistency, behavioral integrity, sharing and delegation of control, communication, and demonstration of concern. Four of these categories are addressed in more-or-less the same way within the corporate and democratic approach to ethics programs. Ideally, in both approaches, the categories 'behavioral consistency' (predictable behavior), 'behavioral integrity' (do what you say), 'communication' (accurate information and explanations for decisions), and 'demonstration of concern' (protecting the interests of employees) are emphasized. However, in the democratic approach, the category of 'sharing and delegation of control' is also well elaborated. The heart of the mini-company process is based around this point. The effects are twofold, on the one hand, sharing and delegation of control gives employees the opportunity to protect their interests in the decision making process and in the execution process. On the other hand, sharing and delegation of control has an important symbolic meaning, it demonstrates trust in, and respect for, the employees. For these reasons, sharing of control (participation) and delegation of control (democracy, or the authority to control and make decisions about ones own workplace) are key components in initiating trust ${ }^{27}$ (see also Discoll, 1978; Deci et al., 1989). To complete the circle, sharing and delegation lead towards internalization and contextualization of corporate norms. These considerations show that trust, power and influence, and the effectiveness of ethics programs are closely related.

\section{CONCLUSION}

In the corporate approach to ethical programs, attention is focused on the role of the manager and on the standardization of ethical behavior at a corporate level. In the democratic approach, attention is focused on the role of the whole organization and on the elaboration and specification of corporate standards by the employees in the context of their workplace.

The corporate and the democratic approaches have many things in common. Both emphasize the lead of management, the importance of an ethics program, the organizational conditions to implement such a program, and a culture that stimulate responsible behavior. The difference between the two is in the implementation process.

We have shown that, with the democratic approach, some of the limitations of the corporate approach can be overcome. Firstly, the participative process of the democratic approach does lead to the internalization of ethical values. In the mini-company process, the employees develop these values for themselves. In addition, striving for continuous improvement implies that legal regulations do not only function as a limit, but also function as a standard to be surpassed. Secondly, the democratic approach as proposed in this study does not lead towards a legalistic point of view: a whole range of ethical behavior is covered. The corporate ethics program will function as a framework in which the corporate norms are specified and elaborated. Thirdly, the democratic approach leads towards contextualization. Shop floor management 
practice shows that general norms and standards cannot be applied unambiguously. Management, often too readily, takes it for granted that a deployed ethical norm or standard will be understood in line with its intentions. Corporate norms and standards have to be specified and elaborated in the context of each employee's workplace in order to understand their meaning, reach and limitations. The mini-company process offers a method to realize this objective. Finally, the whole improvement process is an implicit and continuous reconfirmation of the ethical norm and its specification for every workplace. The symbolic value of the whole improvement process should not be underestimated.

The Roermond case study has shown that a democratic approach results in a large amount of power throughout the whole organization, and a high level of trust between the different hierarchical levels. It has been argued that a large amount of power and a high level of trust stimulates the effectiveness of an ethics program. Furthermore, it has been suggested that the control graphs, as developed by Tannenbaum, can be interpreted as a responsibility graph.

Overall, we claim that a participative democracy will contribute strongly to the development of a responsible organization.

\section{NOTES}

${ }^{1}$ Collins (2000), The Quest to improve the Human Condition; The Final 1500 Articles in the Journal of Business Ethics, Journal of Business Ethics, 26, 1-73

2 Jan de Leede, André H.J. Nijhof and Olaf A M. Fisscher, "The Myth of Self-Managing Teams; A Reflection on the Allocation of Normative Responsibility between Individuals, Teams and the Organisation", Journal of Business Ethics 21 2-3 (1999), 203-215.

${ }^{3}$ See for example Eric L. Trist, "The Sociotechnical Perspective; The evolution of sociotechnical systems as a conceptual framework and as an action research program", in: Andrew H. van de Ven and William F. Joyce, Perspectives on organization design and behaviour (New York: John Wiley \& Sons, 1981); Björn Gustavsen, Dialogue and development (Assen: Van Gorcum, 1992); Ulbo de Sitter, Johan F. den Hertog, Ben Dankbaar, "From complex organizations with simple jobs to simple organizations with complex jobs", Human Relations, 50-5 (1997), 497-534.

${ }^{4}$ Bartels, R. (1967), A model for ethics in marketing, Journal of Marketing, 1, 20-26.

${ }^{5}$ Examples of interactionist models are provided by O.C. Ferrell and L.G. Gresham, "A Contingency Framework for Understanding Ethical Decision Making in Marketing”, Journal of Marketing, 49 (1985), 87-96 and by L.K. Trevino, "Ethical Decision Making in Organizations; A Person-Situation Interactionist Model”, Academy of Management Review, 11 (1986), 601-617. An example of an issue-related model is by T.M. Jones, "Ethical Decision Making by Individuals in Organizations, An Issue-Contingent Model", Academy of Management Review, 16 (1991), 366-395. Overviews of the similarities and differences among the distinct models are provided in the preceding reference, and by M. Bommer, $\mathrm{C}$. Grato, J. Gravander and M. Tuttle, "A behavioral model of ethical and unethical decisionmaking”, Journal of Business Ethics, ?? (1987), 265-280. 
${ }^{6}$ On page 358 of O.C. Ferrell, D.T. Le Clair and L. Ferrell, "The federal Sentencing Guidelines for organizations; A framework for ethical compliance", Journal of Business Ethics, ?? (1998), 353-363.

${ }^{7}$ See pages 41-42 of G.R. Weaver, L.K. Trevino and P.L. Cochran, "Corporate Ethics Programs as Control Systems; Influences of Executive Commitment and Environmental Factors", Academy of Management Journal, (1999), 41-57.

${ }^{8}$ Linda S. Paine, "Managing for Organizational Integrity”, Harvard Business Review, MarchApril (1994), 106-117.

${ }^{9}$ See J.T. Delaney and D. Sockell, "Do company ethics training programs make a difference? An empirical analysis", Journal of Business Ethics, ?? (1992), 719-728; D.P. Quinn and T.M. Jones, "An Agent Morality View of Business Policy", Academy of Management Review, 201 (1995), 22-42.

${ }^{10}$ See G.R. Weaver, L.K. Trevino and P.L. Cochran, "Corporate Ethics Programs as Control Systems; Influences of Executive Commitment and Environmental Factors", Academy of Management Journal, (1999), 41-57.

11 See Margareth Urban Walker, "Moral Understandings: Alternative "Epistemology" for a Feminist Ethics", (Originally published in 1989), in Justice and Care: Essential Readings in Feminist Ethics, eds. Virginia Held, Colorado: Westview Press of HaperCollins Publishers, pp. 139-152; S. Hekman, Moral Voices, Moral Selves; Carol Gilligan and Feminist Moral Theory (Oxford: Blackwell Publishers, 1995).

${ }^{12}$ See Merrelyn Emery (ed), Participative design for participative democracy, (Canberra: Centre for Continuing Education, The Australian National University, 1993). A participative democracy has to be clearly distinguished from a representative one. In a representative democracy, representatives of the organization are elected to one or another board, e.g. a works council or a board of management. These representatives can influence the decision processes at management level. In a participative democracy both the scope and the character is different: it is intended that all employees should have the authority to control and to decide about their own workplace.

${ }^{13}$ The lead author was, during the research phase, the factory manager of this business unit. The second author carried out the participative observations, the interviews, and the survey. This case has been described in detail in Maarten Verkerk, Jan de Leede \& Henk van der Tas, Market-oriented production management (Deventer: Kluwer Bedrijfsinformatie, 1997, in Dutch) and in Jan de Leede, Bottom-up innovation $\mathrm{PhD}$ thesis (Deventer, Kluwer Bedrijfsinformatie, 1997, in Dutch).

${ }^{14}$ Arnold S. Tannenbaum, Control in Organizations, (New York: McGraw-Hill, 1968). 
${ }^{15}$ Kiyoshi Suzaki, The new shop floor management; Empowering people for continuous improvement (New York: The Free Press, 1993).

${ }^{16}$ See Frans M. van Eijnatten, The paradigm that changed the workplace (Assen: Van Gorcum, 1993). The Australian and the Scandinavian variants of STS both stress the participative process in designing effective and democratic workplaces. They indicate that the participation of employees in design processes leads to commitment, see Merrelyn Emery (ed), Participative design for participative democracy, (Canberra: Centre for Continuing Education, The Australian National University, 1993). Furthermore, dialogues within the company and between companies lead to involvement, change and commitment according to Björn Gustavsen, Dialogue and development (Assen: Van Gorcum, 1992). The North American variant stresses the role of experts in the sociotechnical design of the organization, see James C.Taylor and David F. Felten, Performance by Design. Sociotechnical Systems in North America (New Jersey: Prentice Hall, 1993).

${ }^{17}$ Frans M. van Eijnatten and Ad H. van der Zwaan, "The Dutch IOR approach to organizational design: An alternative to Business Process Reengineering?", Human Relations, 51-3 (1998), 289-317.

${ }^{18}$ See page 503 of Ulbo de Sitter, Johan F. den Hertog, Ben Dankbaar, "From complex organiztions with simple jobs to simple organizations with complex jobs", Human Relations, 50-5 (1997), 497-534.

${ }^{19}$ Suzaki has not developed a detailed design theory and design methodology. He gives some general principles for designing an organization, e.g. paralleling production lines. These principles are in agreement with the design theory of the Dutch variant of STS. See also Kiyoshi Suzaki, The new manufacturing challenge; Techniques for continuous improvement, (New York: The Free Press, 1987).

${ }^{20}$ See the work of Gustavsen, Emery, Suzaki, 1993, De Leede, Verkerk et al.. See also Ron E. Purser, and Steve Cabana, The self managing organization; How leading companies are transforming the work of teams for real impact (New York: The Free Press, 1998).

${ }^{21}$ See for example, Patricia Werhane, 1985, Persons, Rights and Corporations, Prentice Hall Inc., Englewood Cliffs

${ }^{22}$ Ulbo de Sitter, on page 172 of Frans M. van Eijnatten, The paradigm that changed the workplace (Assen: Van Gorcum, 1993).

${ }^{23}$ See Chris Argyris, "Empowerment: the emperor's new clothes", Harvard Business Review, May-June (1998), 98-105.

${ }^{24}$ Page 393 in Larue Tone Hosmer, "Trust: the connecting link between organizational theory and philosophical ethics", Academy of Management Review, 20-2 (1995), 379-403. 
${ }^{25}$ See for example the article by Hosmer, and in the same journal the article by R.C. Mayer, J.H. Davis, and F.D. Schoorman, "An integrative model of organizational trust", Academy of Management Review, 20-3, 709-734.

${ }^{26}$ Ellen M.Whitener, Susan E. Brodt, M. Audrey Korsgaard and Jon M. Werner, "Managers as initiators of trust: an exchange relationship framework for understanding managerial trustworthy behavior", Academy of Management Review, 23-3 (1998), 513-530.

${ }^{27}$ See also James W. Driscoll, "Trust and participation in organizational decision making as predictors of satisfaction", Academy of Management Journal, 21-1 (1978), 44-56; and E.L. Deci, J.P. Connell and R.M. Ryan, "Self-determination in a work organization", Journal of Applied Psychology, 74-4 (1989), 580-590. 